\title{
Covariation between gross primary production and ecosystem respiration across space and the underlying mechanisms: A global synthesis
}

\author{
Zhi Chen ${ }^{\mathrm{a}, \mathrm{b}}$, Guirui Yu ${ }^{\mathrm{a}, *}$, Xianjin Zhu ${ }^{\mathrm{a}}$, Qiufeng Wang ${ }^{\mathrm{a}}$, Shuli Niu ${ }^{\mathrm{a}}$, Zhongmin $\mathrm{Hu}^{\mathrm{a}}$ \\ a Synthesis Research Center of Chinese Ecosystem Research Network, Key Laboratory of Ecosystem Network Observation and Modeling, \\ Institute of Geographic Sciences and Natural Resources Research, Chinese Academy of Sciences, Beijing 100101, China \\ ${ }^{\mathrm{b}}$ University of Chinese Academy of Sciences, Beijing 100049, China
}

\section{A R T I C L E I N F O}

\section{Article history:}

Received 11 July 2014

Received in revised form 12 January 2015

Accepted 13 January 2015

Available online 23 January 2015

\section{Keywords:}

Gross primary production

Ecosystem respiration

RE/GPP

Covariation

Spatial variations

Global terrestrial ecosystems

\begin{abstract}
A B S T R A C T
Gross primary production (GPP) and ecosystem respiration (RE) are two important processes in the terrestrial carbon cycle. Understanding the relationships between GPP and RE across space, as well as the underlying mechanisms, is helpful for understanding the terrestrial carbon cycle and predicting the global carbon budget. In this study, we investigated the correlation between the spatial variations in GPP and RE by compiling carbon flux data from 264 sites across the Asian, European, North American, South American, African, and Oceanian regions. The results indicated that GPP and RE covaried across space regionally and globally $(P<0.001)$. The spatial variations in GPP explained $66-98 \%$ of the variations in $\mathrm{RE}$ in the six regions (approximately explained $60-76 \%$ when considered the effects of self-correlation caused by current flux partitioning algorithm), and it explained $90 \%$ of RE variations at the global scale (about 70\% when considered the effects of self-correlation). RE/GPP values were not significantly different among the six regions or between the two hemispheres. RE/GPP values consistently averaged at $0.87 \pm 0.04$ along the spatial variations in climate and vegetation index. This covariation between GPP and $\mathrm{RE}$ across space is largely attributed to the parallel responses of GPP and RE to the common climatic and vegetation factors, but the underlying mechanism lies in productivity as the primary and direct substrate supplier for respiration which fundamentally constrains RE. These results suggest that the variation in photosynthate availability is the dominant driver for respiration across space and that this process must be fully considered in the cross-site RE comparisons.
\end{abstract}

(ㄷ) 2015 Elsevier B.V. All rights reserved.

\section{Introduction}

Global $\mathrm{CO}_{2}$ emissions are projected to continue to rise. Increasing terrestrial ecosystem carbon (C) uptake has been proposed as an effective way to mitigate future climate change (Lal, 2012). Gross primary production (GPP) and ecosystem respiration (RE) are two essential components of the terrestrial carbon cycle. GPP represents the gross $\mathrm{CO}_{2}$ uptake through photosynthesis by all plants at the ecosystem level (Chapin et al., 2002; Luyssaert et al., 2007). RE is the gross $\mathrm{CO}_{2}$ release from the ecosystem through both autotrophic respiration $\left(R_{\mathrm{a}}\right)$, which provides energy for the growth and maintenance of foliage, wood, and roots (Chapin et al., 2002; Waring et al.,

\footnotetext{
* Correspondence to: Institute of Geographic Sciences and Natural Resources Research, Chinese Academy of Sciences, 11A, Datun Road, Chaoyang District, Beijing 100101, China. Tel.: +86 10 64889432; fax: +86 1064889432 .

E-mail address: yugr@igsnrr.ac.cn (G. Yu).
}

1998), and heterotrophic respiration $\left(R_{\mathrm{h}}\right)$, which derives from the process of decomposition through microbial activities (Luyssaert et al., 2007). Understanding the variations in GPP and RE and their relationships is helpful for better understanding the terrestrial carbon cycle and predicting the global carbon budget.

The eddy covariance technique provides a useful independent approach to the quantification of GPP and RE by measuring and partitioning net ecosystem exchange (NEE). Extensive research has been conducted to explore the GPP and RE seasonal dynamics (Goulden et al., 2004), interannual variability (Wilkinson et al., 2012; Yu et al., 2008), and responses to extreme droughts (Ciais et al., 2005; Reichstein et al., 2007a) and disturbances (Amiro et al., 2010; Dore et al., 2010). From these findings, researchers have gradually recognized that GPP and RE are not independent, but are two strongly associated ecological processes. RE is strongly coupled with GPP across timescales (Dunn et al., 2007; Migliavacca et al., 2011). For example, RE follows the same dynamic patterns as GPP from daily to seasonal scales (Krishnan et al., 2009; Migliavacca 


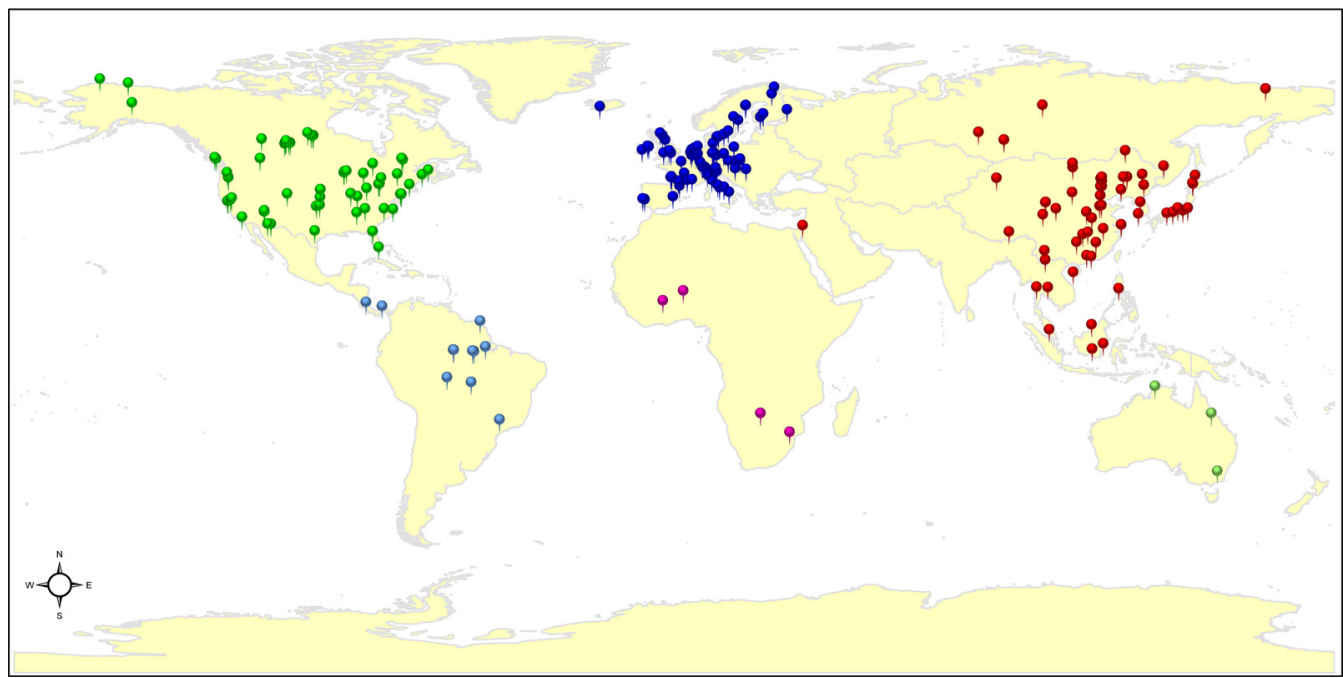

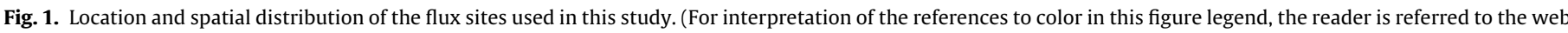
version of this article.)

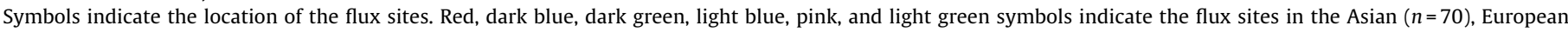
$(n=91)$, North American $(n=83)$, South American $(n=13)$, African $(n=4)$, and Oceanian regions $(n=3)$, respectively.

et al., 2011; Thomas et al., 2009). Annually, GPP and RE are both enhanced in humid years, but repressed in dry years (Hussain et al., 2011; Rodrigues et al., 2011); especially, both of them are remarkably reduced in extreme drought years (Granier et al., 2007; Reichstein et al., 2007a).

In fact, the tightly coupled relationship between GPP and RE is not only temporal, but occurs at the spatial scale as well. Janssens et al. (2001) showed that annual RE increases linearly with GPP across 18 European forest ecosystems. Law et al.(2002) gave further evidence for the linear correlation between GPP and RE across space by examining 34 FLUXNET sites. Yu et al. (2013) showed that GPP and RE exhibit tight covariation across space in China.

Although several studies have examined the relationships between the spatial variations in GPP and RE, the study sites were mainly located in the Northern Hemisphere, particularly concentrated in the North America and Europe (Janssens et al., 2001; Law et al., 2002; Reichstein et al., 2007b). We still lack knowledge about the covariation between GPP and RE in Asia and in the Southern Hemisphere. More importantly, the underlying mechanism for the GPP and RE covariation is not fully clear, and the ecological implications are much less discussed.

This study was conducted to analyze carbon flux data at the global scale to: (1) reveal the covariation between GPP and RE across global ecosystems, (2) explore the underlying mechanisms for the covariation between GPP and RE, (3) and discuss the ecological implications of the covariation.

\section{Materials and methods}

\subsection{Data collection and screening}

We collected global carbon flux data (GPP and RE) measured by the eddy covariance technique from published literature over the past two decades (1990-2010). The data were required to be filtered and corrected by researchers of each site, using coordinate rotation, WPL correction, storage flux calculation, outlier filtering, nighttime flux correction, NEE gap filling and partitioning. Additionally, data must continuously be measured at least for an entire year, and the annual GPP and RE values were both available.

In total, 913 site-year GPP and RE records from 264 sites were included in this study. These studied sites span from $35.66^{\circ} \mathrm{S}$ to $71.32^{\circ} \mathrm{N}$ in latitude, and from $156.63^{\circ} \mathrm{W}$ to $161.34^{\circ} \mathrm{E}$ in longitude across the Asian (70 sites), European (91 sites), North American ( 83 sites), South American (13 sites), African (4 sites), and Oceanian regions (3 sites) (Fig. 1). They covered five major climate zones: tropical, subtropical, temperate, boreal, and subarctic, and included eight biomes: evergreen broad-leaved forests ( 22 sites), evergreen needle-leaved forests ( 68 sites), deciduous broad-leaved forests ( 26 sites), deciduous needle-leaved forests ( 5 sites), mixed forests (14 sites), grasslands (67 sites), croplands ( 34 sites), and wetlands ( 28 sites). The locations, ecosystem types, and GPP and RE values are listed in Table S1 in the Supplements.

\subsection{Climatic data}

Climatic variables including the mean annual temperature (MAT), mean annual precipitation (MAP), and mean annual solar radiation (MAR) were also collected. For sites missing temperature and precipitation data, we used the global surface summary of daily data produced by the National Climatic Data Center (NCDC) (ftp://ftp.ncdc.noaa.gov/pub/data/gsod/) from their neighboring meteorological stations to fill the gaps. Ten sites were filled for temperature, two sites for precipitation, and six sites for both. MAR was less available compared to MAT and MAP, so we extracted MAR data from the Climate Research Unit (CRU05) Monthly Climate Database (http://daac.ornl.gov/ISLSCP_II/guides/cru_monthly_mean_xdeg.html) provided by the International Satellite Land Surface Climatology Project (ISLSCP). The 30-year (1961-1990) MAR from the CRU database showed good agreement $\left(R^{2}=0.79\right)$ with the MAR measured at the flux tower sites during the period of interest. In the analysis, we used the 30-year averaged MAR from the CRU database for uniformity.

\subsection{Vegetation data}

The Enhanced Vegetation Index (EVI) combines the reflectance values from multiple spectral bands and can provide useful land cover information (Huete et al., 2002). The satellite-borne Moderate Resolution Imaging Spectroradiometer (MODIS) data product (MOD13Q1) provides global EVI at a spatial resolution of $250 \mathrm{~m}$ and a temporal resolution of 16 days from 2000 to present (Huete et al., 2002). For each flux site, we obtained its MOD13Q1 subset from the Oak Ridge National Laboratory's Distributed Active Archive Center (http://daac.ornl.gov/MODIS/). Accounting for the $1 \mathrm{~km}$ spatial 

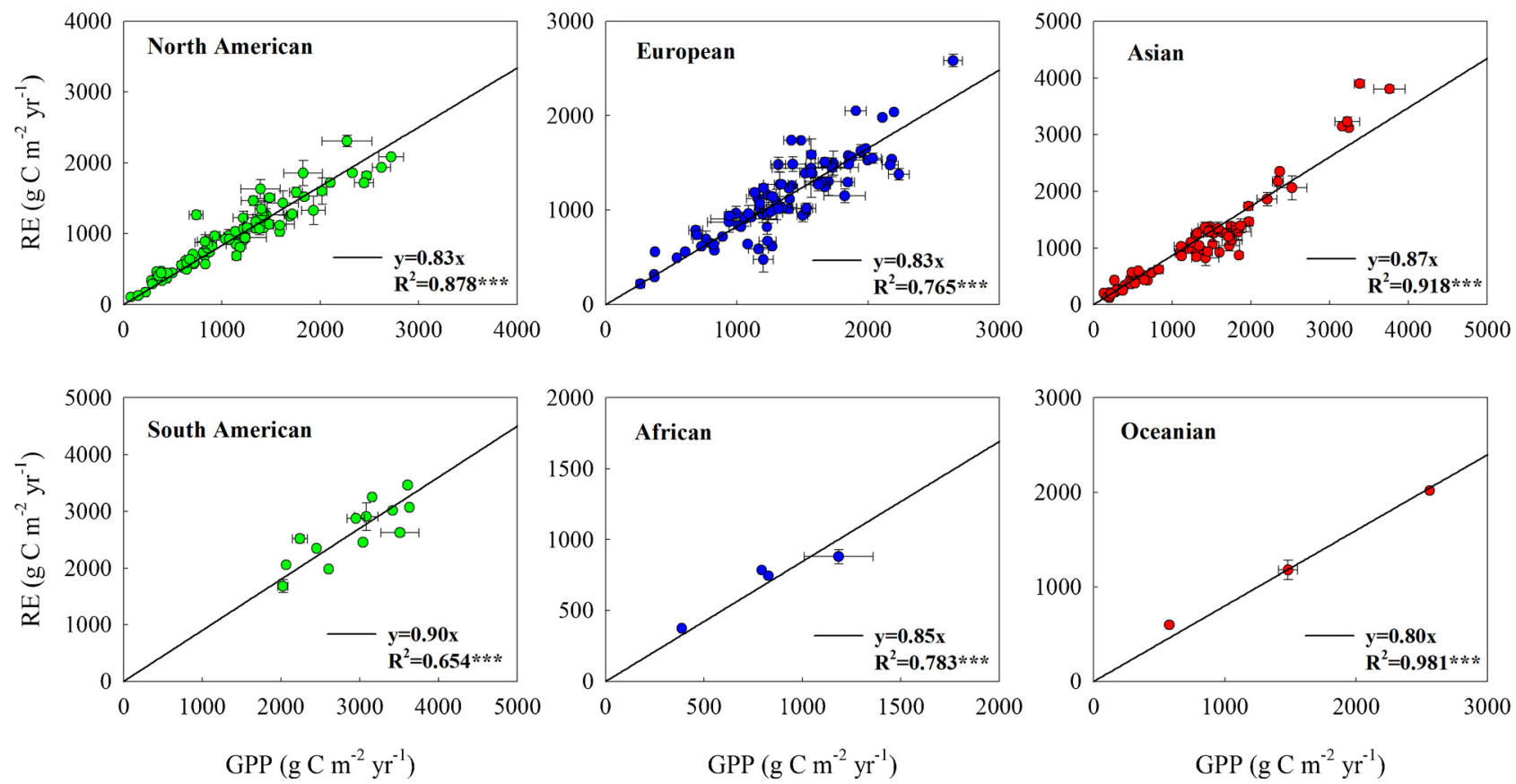

Fig. 2. Relationships between the spatial variations in GPP and RE in the North American, European, Asian, South American, African, and Oceanian regions.

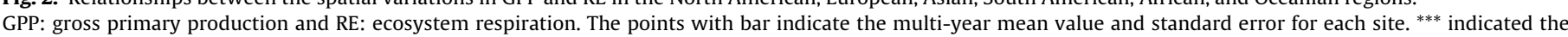
regression equation was significant at the 0.001 level.

footprint of the flux tower (Göckede et al., 2004) and the inherent geolocation error in the MODIS data, we extracted regions consisting of 81 pixels with a $1 \mathrm{~km}$ radius centered on the flux tower. We examined the quality of the EVI value for each pixel within the extracted area using the pixel reliability flags included in the product. The good pixels were filtered with pixel reliability flags of 0 or 1 . At the 16-day time scale, we only averaged the EVI values for every 16 days from 2000 to 2010 when more than a quarter of pixels were of good quality. Otherwise, we treated the day as missing and used the multiple-year averaged EVI for the missing day to fill. Finally, we calculated the multiple-year averaged EVI for each flux site.

\subsection{Dataset uncertainty analysis}

In the dataset, differences between sites existed in terms of the measurement system types, friction velocity $\left(u^{*}\right)$ thresholds, NEE gap filling, and the partitioning methods. Open-path (OPEC) and closed-path eddy covariance (CPEC) systems were used separately or in combination among sites. However, inter-comparison studies indicated that whether an OPEC or CPEC system was used did not represent a serious source of bias (Haslwanter et al., 2009), and the measurement error between the two systems was reported to be less than 5\% (Baldocchi et al., 2001). The $u^{*}$ threshold varied among sites, because it was identified according to local topography, vegetation, and weather. In general, the $u^{*}$ threshold lies between 0.1 to $0.4 \mathrm{~m} / \mathrm{s}$ (Reichstein et al., 2005). In our dataset, the $u^{*}$ thresholds fell into this range (Table S2). Gaps in NEE are inevitable due to operational and micrometeorological constraints. Mean Diurnal Variation (MDV), Look-Up Tables (LookUp), Marginal Distribution Sampling (MDS), Non-linear Regression (NLR), and Artificial Neural Network (ANN) were used for NEE gap filling in the dataset. Between these different gap filling approaches no obvious differences were reported in comparison studies (Falge et al., 2001; Moffat et al., 2007; Papale et al., 2006). The effect of gap filling on the annual sum of NEE falls within a range of $\pm 25 \mathrm{~g} \mathrm{C} \mathrm{m}^{-2}$ year $^{-1}$ using most approaches (Moffat et al., 2007).
Different flux partitioning methods would exert much direct influence on GPP and RE values. At present, there is no standard flux partitioning method in use (Desai et al., 2008; Lasslop et al., 2010; Reichstein et al., 2005). Two approaches commonly used to separate NEE into GPP and RE are the nighttime data-based (NB) method in which respiration measured at night were extrapolated to the daytime based on the responses of respiration to air or soil temperature (Lloyd and Taylor, 1994; Reichstein et al., 2005), and the daytime data-based (DB) method in which light-response curves were fitted to daytime NEE measurements and respiration was estimated from the intercept, then respiration was extrapolated into the nighttime using air or soil temperature measured during the night (Gilmanov et al., 2003; Lasslop et al., 2010). These two broad approaches are generally in good agreement through extensive comparison across multiple sites (Falge et al., 2002; Lasslop et al., 2010; Stoy et al., 2006). In our dataset, more than $73 \%$ of the sites $(n=194)$ commonly applied the nighttime data-based method (Fig. S1). To further examine the potential bias caused by the imperfect uniform flux partitioning, we performed the analysis using a subset of the data from the same flux partitioning (NB). As shown in Figs. S2 and 3, a similar pattern was found from the eddy covariance data when using either the combined methods (NB and DB) or the common NB method. This result suggested that the slightly

Table 1

Means and standard errors (S.E.) of the RE/GPP values in the forest, cropland, grassland, and wetland ecosystems in the six regions.

\begin{tabular}{|c|c|c|c|c|c|c|c|c|}
\hline \multirow[t]{2}{*}{ RE/GPP } & \multicolumn{2}{|l|}{ Forest } & \multicolumn{2}{|c|}{ Cropland } & \multicolumn{2}{|c|}{ Grassland } & \multicolumn{2}{|c|}{ Wetland } \\
\hline & Mean & S.E. & Mean & S.E. & Mean & S.E. & Mean & S.E. \\
\hline Asian & 0.82 & 0.02 & 0.79 & 0.04 & 0.93 & 0.07 & 0.79 & 0.05 \\
\hline European & 0.79 & 0.03 & 0.79 & 0.03 & 0.95 & 0.03 & 0.82 & 0.03 \\
\hline North American & 0.90 & 0.03 & 0.84 & 0.03 & 0.97 & 0.04 & 0.96 & 0.07 \\
\hline South American & 0.89 & 0.03 & - & - & 1.12 & - & - & - \\
\hline Oceanian & 0.79 & - & - & - & 0.91 & 0.12 & - & - \\
\hline African & - & - & - & - & 0.90 & 0.05 & - & - \\
\hline Sig. & 0.012 & & 0.345 & & 0.637 & & 0.069 & \\
\hline
\end{tabular}

Difference is significant when sig. $<0.05$. 

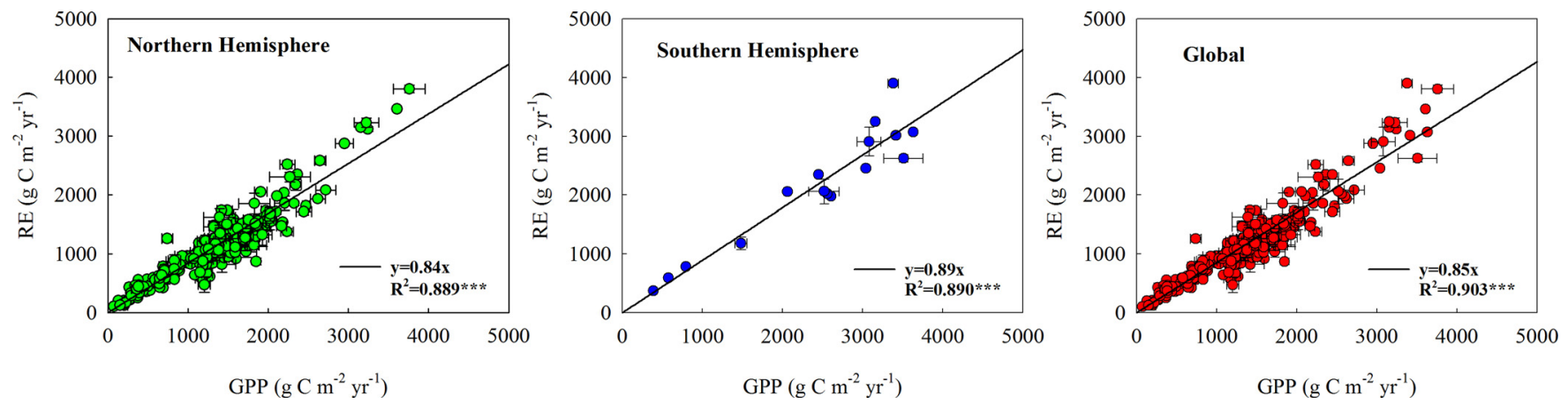

Fig. 3. Relationships between the spatial variations in GPP and RE in the Northern Hemisphere, the Southern Hemisphere and the globe.

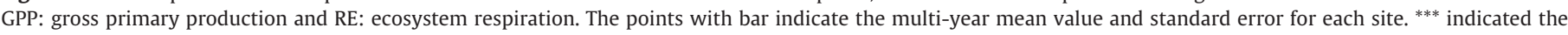
regression equation was significant at the 0.001 level.

different flux partitioning among our studied sites did not significantly affect the relationships between GPP and RE across space. Detailed measurement systems and data processing approaches applied for each site were explicitly shown in Table S2 in the Supplements.

\subsection{Data analysis}

\subsubsection{Path analysis}

Path analysis is an extension of multiple regression analysis that is used to evaluate the dependence of the target variable on several influence variables. It is particularly useful in evaluating data where independence is not certain and when a priori causal connection among variables is well known (Huxman et al., 2003; Li, 1981).

Our model was designed to assess the drivers of the spatial variations in GPP and RE. In this model, we assumed that climatic variables (MAT, MAP, and MAR) and the vegetation variable (EVI) are important in controlling the spatial variations in GPP and RE, and their interrelated paths provide the ways to evaluate direct and indirect responses. To construct the path diagram, we conducted four multiple regressions on multi-year averaged annual data using the Statistical Package for the Social Science (SPSS) v16.0 software (SPSS, 2007). We used the standardized partialregression coefficient to describe the path strengths generated from the following analyses: (1) GPP regressed on RE, the mean annual temperature, precipitation, radiation, and vegetation index, (2) RE regressed on the mean annual temperature, precipitation, radiation, and vegetation index, (3) the vegetation index regressed on the mean annual temperature, precipitation, and radiation, (4) the mean annual temperature regressed on radiation. From the path diagrams, we evaluated the following paths and controls: (1) the direct and indirect effects of the mean annual temperature, precipitation, and vegetation index over GPP, (2) the direct and indirect effects of the mean annual temperature, precipitation, and vegetation index over RE, (3) the direct effects of GPP over RE. The direct effects were taken as the standardized partial-regression coefficient, and the indirect effects were the sums of the standardized

Table 2

Means and standard errors (S.E.) of the RE/GPP values in the forest, cropland, grassland, and wetland ecosystems for the Northern Hemisphere (N.H.), the Southern Hemisphere (S.H.) and the globe.

\begin{tabular}{|c|c|c|c|c|c|c|c|c|c|c|}
\hline \multirow[t]{2}{*}{ RE/GPP } & \multicolumn{2}{|l|}{ Forest } & \multicolumn{2}{|c|}{ Cropland } & \multicolumn{2}{|c|}{ Grassland } & \multicolumn{2}{|c|}{ Wetland } & \multicolumn{2}{|l|}{ Total } \\
\hline & Mean & S.E. & Mean & S.E. & Mean & S.E. & Mean & S.E. & Mean & S.E. \\
\hline N.H. & 0.84 & 0.02 & 0.80 & 0.02 & 0.95 & 0.03 & 0.86 & 0.04 & 0.87 & 0.01 \\
\hline S.H. & 0.89 & 0.04 & - & - & 0.95 & 0.05 & - & - & 0.91 & 0.03 \\
\hline Sig. & 0.343 & & - & - & 0.992 & & - & - & 0.387 & \\
\hline Global & 0.85 & 0.01 & 0.80 & 0.02 & 0.95 & 0.03 & 0.86 & 0.04 & 0.87 & 0.01 \\
\hline
\end{tabular}

Difference is significant when sig. $<0.05$. partial-regression coefficients across all paths to the variables of interest.

\subsubsection{Statistical analysis}

All data were analyzed using SPSS v16.0 software (SPSS, 2007). We calculated the deviation value $\left(t^{*}\right)$ to examine the difference of the regression slopes among the six regions and between the Northern and Southern Hemispheres. $T^{*}$ was estimated as $t^{*}=$ $\left(b_{1}-b_{2}\right) / \sqrt{\left(s_{1}^{2}+s_{2}^{2}\right)}$, where $b_{1}$ and $b_{2}$ were the regression slopes, and $s_{1}$ and $s_{2}$ were the standard errors of the regression slopes. The null hypothesis was that the regression slope $b_{1}$ was equal to $b_{2}$. If $t^{*}>t$, the hypothesis was rejected and vice versa, where $t$ was derived from the $t$-test table for the degree of freedom ( $d f$ ) of $n_{1}+n_{2}-4\left(n_{1}\right.$ and $n_{2}$ are the number of sites used in the regression for each region) at the $\alpha=0.01$ level. One-way Analysis of Variance (ANOVA) and Duncan tests were used to examine the differences in $\mathrm{RE} / \mathrm{GPP}$ among the six regions and the four ecosystem types at a significance level of 0.05. An independent-sample $t$-test was applied to analyze the differences in RE/GPP between the Northern and Southern Hemispheres at a significance level of 0.05 .

\section{Results}

\subsection{Relationships between the spatial variations in GPP and RE in the six regions}

The spatial variations in RE were strongly related to the spatial variations in GPP in a linear and positive way in the North American, European, Asian, South American, African, and Oceanian regions (Fig. 2). The $P$ values for all of the regression equations were significant at the 0.001 level. In the Oceanian, Asian, North American, African, European, and South American regions, the spatial variations of GPP contributed $98 \%, 92 \%, 88 \%, 78 \%, 77 \%$, and $65 \%$ to the spatial variations of RE, respectively. The regression slopes for the six regions varied in the range of $0.80-0.90$, but there was no significant difference in the regression slopes among the six regions $\left(t^{*}=0.19-2.31<2.61-5.81\right.$ at $99 \%$ confidence level) (Fig. 2).

Table 3

Matrix with the correlation coefficients for the flux variables (GPP and RE), the climatic variables (MAT, MAP, and MAR) and the vegetation index (EVI).

\begin{tabular}{lllllll}
\hline & MAT & MAP & MAR & EVI & GPP & RE \\
\hline MAT & 1 & $0.620^{* * *}$ & $0.540^{* * *}$ & $0.513^{* * *}$ & $0.643^{* * *}$ & $0.627^{* * *}$ \\
MAP & & 1 & 0.056 & $0.637^{* * *}$ & $0.700^{* * *}$ & $0.702^{* * *}$ \\
MAR & & & 1 & -0.08 & 0.049 & 0.055 \\
EVI & & & & 1 & $0.723^{* * *}$ & $0.717^{* * *}$ \\
GPP & & & & & 1 & $0.951^{* * *}$ \\
RE & & & & & & 1 \\
\hline
\end{tabular}

Indicates significant correlation at the 0.001 level (two-tailed). 

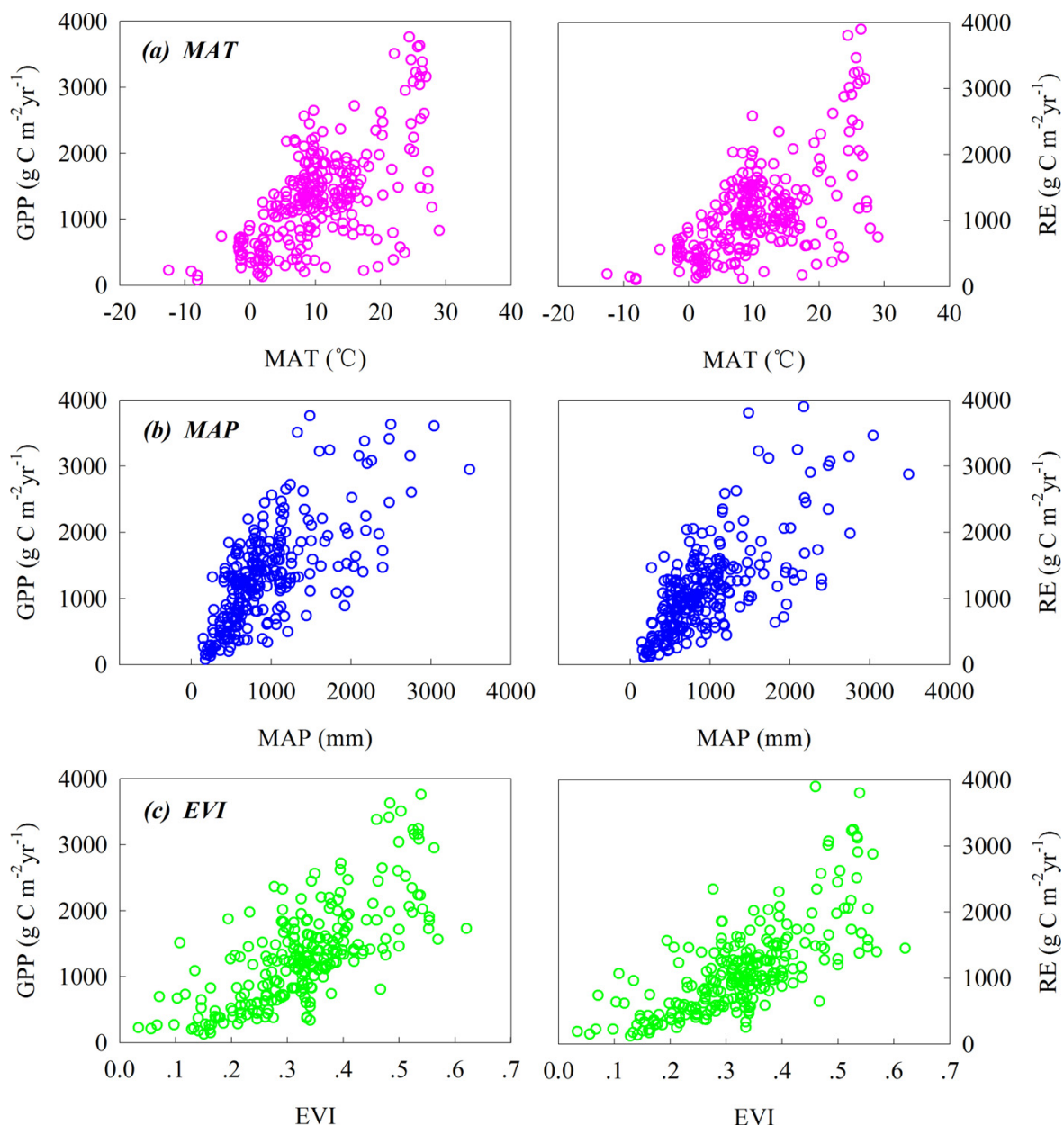

Fig. 4. Responses of GPP and RE to MAT (a), MAP (b), and EVI (c) across space.

GPP: gross primary production, RE: ecosystem respiration, MAT: mean annual temperature, MAP: mean annual precipitation, and EVI: enhanced vegetation index.

The means and variations of RE/GPP in the forest, cropland, grassland, and wetland ecosystems were compared among regions. As shown in Table 1, the mean RE/GPP values in the forests of South and North America were higher than those in the Asian, European, and Oceanian forests $(P=0.012<0.05)$, while the mean $\mathrm{RE} / \mathrm{GPP}$ values in the cropland, grassland, and wetland ecosystems showed no significant difference among the six regions $(P=0.069-0.637>0.05)$.

\subsection{Relationships between the spatial variations in GPP and RE at the hemispheric and global scales}

There were positive linear relationships between the spatial variations in GPP and RE for the Northern Hemisphere (N.H.), the Southern Hemisphere (S.H.) and the globe (Fig. 3). All regression equations were significant $(P<0.001)$ (Fig. 3$)$. In the N.H. and S.H., the spatial variations in GPP explained $89 \%$ of the RE variations. Globally, GPP accounted for $90 \%$ of the spatial variations in RE (Fig. 3). The regression slopes for the N.H. and S.H. varied from 0.84 to 0.89 , but were not significantly different $\left(t^{*}=1.50<2.60, \mathrm{~d} f=260\right.$ at the $99 \%$ confidence level) (Fig. 3).

The means and variations of RE/GPP in the forest, cropland, grassland, and wetland ecosystems for the N.H., the S.H. and the globe were estimated and shown in Table 2. In any of the ecosystem types, the mean RE/GPP values were not significantly different between the N.H. and the S.H. $(P=0.343-0.992>0.05)$ (Table 2$)$. The global RE/GPP values were averaged at $0.80,0.85,0.86$, and 0.95 in the cropland, forest, wetland, and grassland, respectively. The grassland showed a higher mean RE/GPP than the other ecosystems $(P<0.05)$. The global mean RE/GPP value was estimated to be 0.87 based on the available sites in our study.

\subsection{The influences of climatic factors (MAT, MAP, and MAR) and the vegetation factor (EVI) on the relationships between the spatial variations in GPP and RE}

The relationships of climatic factors (MAT, MAP, and MAR) and the vegetation factor (EVI) with GPP and RE were analyzed. The results showed that GPP and RE were related to MAT, MAP, and EVI (correlation coefficients $R=0.627-0.723$ ), but were not related to MAR $R=0.049-0.055$ (Table 3).

Further analysis indicated that GPP and RE exhibited consistent responses to the spatial variations in MAT, MAP, and EVI (Fig. 4). GPP and RE both showed an increasing trend with the increase in MAT, MAP, and EVI across space (Fig. 4(a-c)). Therefore, RE/GPP values did not increase along the MAT, MAP, and EVI across space any more, but instead fluctuated within a range of $0.7-1.2$ for more than $85 \%$ of the terrestrial ecosystems (Fig. 5(a-c)). The RE/GPP values consistently averaged at 0.87 along the variations in climate or vegetation index across space (Fig. $5(\mathrm{a}-\mathrm{c})$ ).

To further investigate how GPP and RE were interrelated with the climatic and vegetation variables, we used path analysis to reveal their direct and indirect effects. The results showed that the spatial variations in GPP and RE were both controlled by variations in MAT, MAP, and EVI, but in different effect paths. The spatial variations in MAT, MAP, and EVI directly controlled the spatial 

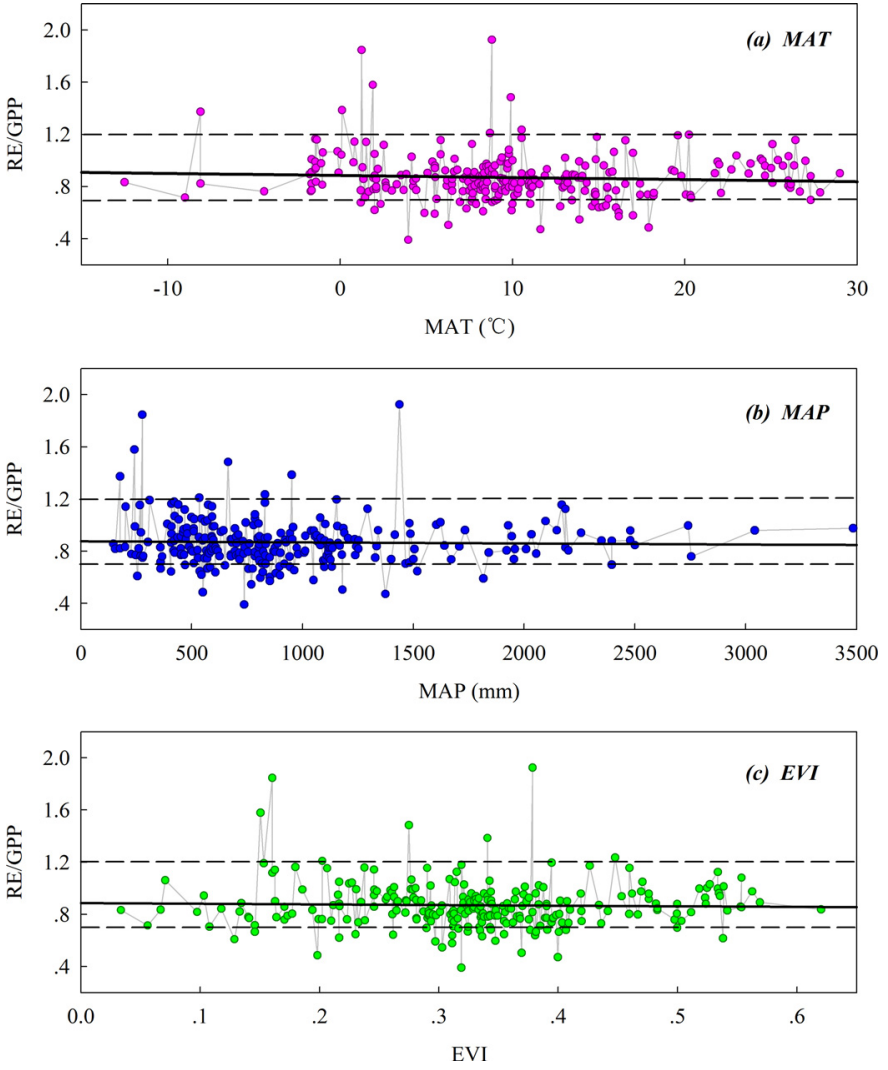

Fig. 5. Variations in RE/GPP values along the MAT (a), MAP (b), and EVI (c) across space.

GPP: gross primary production, RE: ecosystem respiration, MAT: mean annual temperature, MAP: mean annual precipitation, and EVI: enhanced vegetation index.

variations in GPP with direct effects of $0.28,0.30$, and 0.44 , respectively (Fig. 6(a)). Conversely, MAT, MAP, and EVI exhibited much stronger indirect effects on RE (0.34-0.51) than the direct effects (0.01-0.06) (Fig. 6(b and c)). The direct effect of GPP on RE was up to 0.87 (Fig. 6(b)). The results suggested that the spatial variation in GPP was the primary direct driver for the spatial variations in RE, and the impacts of MAT, MAP, and EVI on the spatial variations in RE occurred mainly through their direct effects on the spatial variations in GPP.

\section{Discussion}

\subsection{Covariation between GPP and RE across space}

We found that GPP and RE tightly covaried across space at the regional to the global scale (Figs. 2 and 3). In the European region, Janssens et al. (2001) and Reichstein et al. (2007b) indicated that the annual RE increased linearly with GPP across 18-23 European forests. Our study expands their works by analyzing 4-5 times the number of previously studied European sites with forest, cropland, grassland, and wetland ecosystems included, to reveal that the spatial variations in GPP and RE remain coupled over the broader European region and even with different ecosystems included. The result suggests that GPP and RE covaried across space despite changes in ecosystem types or areas. Yu et al. (2013) previously revealed that GPP and RE tightly covaried across space in China. When we scaled up to the broader Asian region, and extended to the African, South American, and Oceanian regions, covariations between GPP and RE were also observed.

The covariation was similarly found when scaling up to the Northern and Southern Hemispheres, as well as at the global scale (Fig. 3). Based on FLUXNET sites, former studies have revealed the (a)

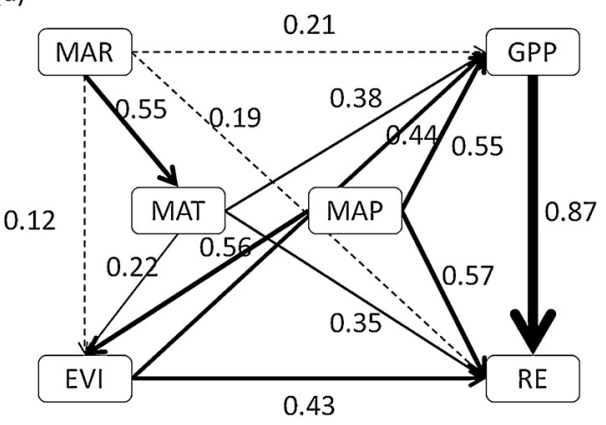

(b)

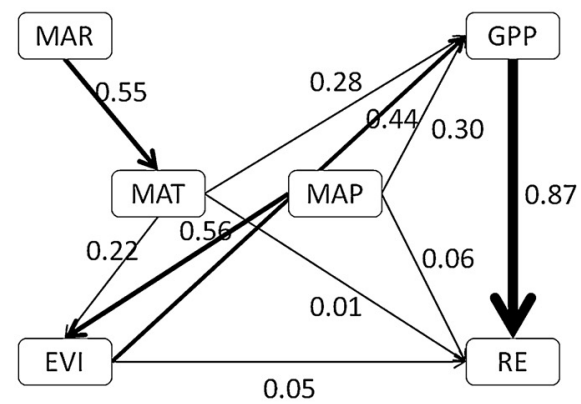

(c)

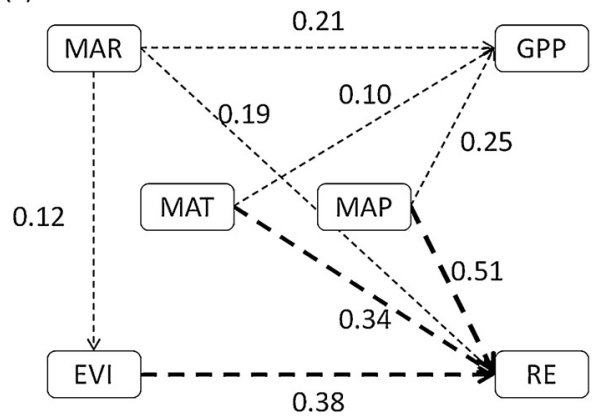

Fig. 6. Path diagrams illustrating the effects of the climatic variables and the vegetation index on the spatial variations in GPP and RE.

(a) Standardized total effects, (b) standardized direct effects, and (c) standardized indirect effects. The thickness of each arrow represents the magnitude of the standardized path coefficients. Solid arrows represent direct effects, and dashed arrows are indirect effects.

GPP: gross primary production, RE: ecosystem respiration, MAT: mean annual temperature, MAP: mean annual precipitation, MAR: mean annual solar radiation, and EVI: enhanced vegetation index

linear covariations between GPP and RE across space in both disturbed and non-disturbed ecosystems globally (Baldocchi, 2008), which confirms our findings that even at the global scale, GPP and $\mathrm{RE}$ retain covariation across space.

\subsection{Underlying mechanisms for the covariation between GPP and RE across space}

An understanding of the underlying mechanisms for the covariation between GPP and RE across space is greatly needed. In this study, we initially found that the spatial variations in GPP and RE are commonly controlled by MAT, MAP, and EVI (Table 3). The controls of temperature and precipitation on the spatial variations in GPP and RE are similarly reported in China (Yu et al., 2013), Asian (Chen et al., 2013; Hirata et al., 2008), European, and American regions (Law et al., 2002; Luyssaert et al., 2007; Reichstein et al., 2007b). Furthermore, we found that GPP and RE responded to the common climatic and vegetation factors in a parallel way across 


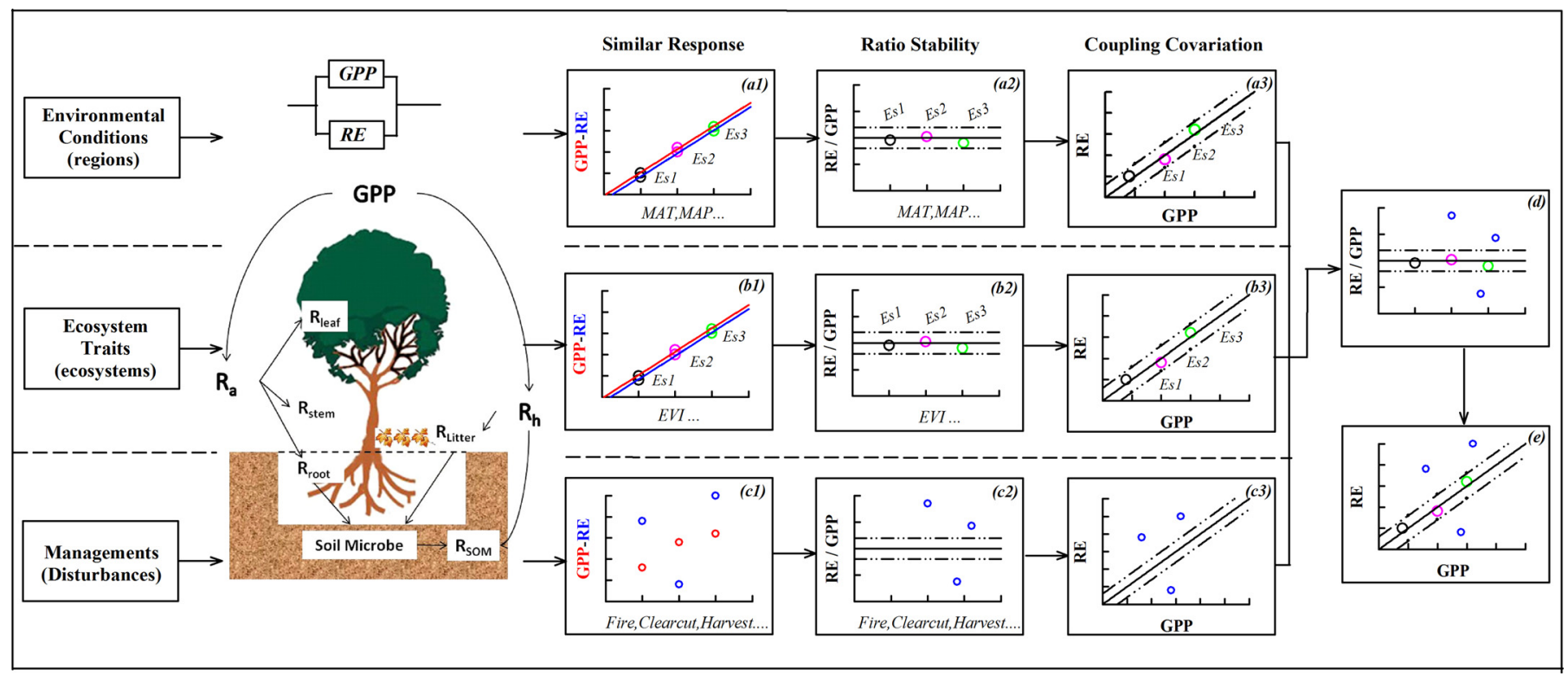

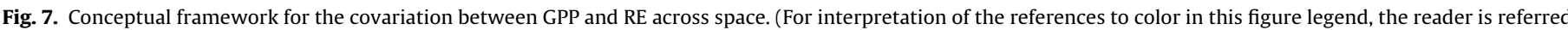
to the web version of this article.)

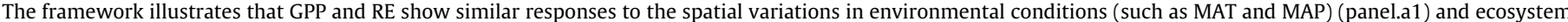

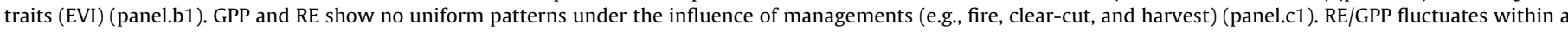

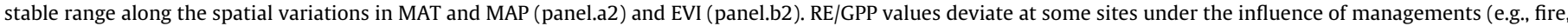

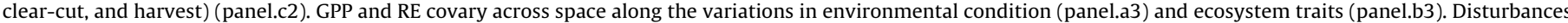

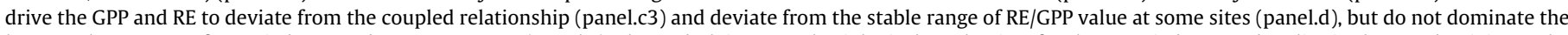

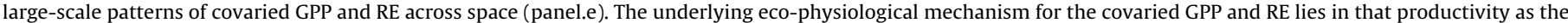
primary and direct supplier of substrate for respiration (including autotrophic and heterotrophic respiration) which fundamentally constrains RE.

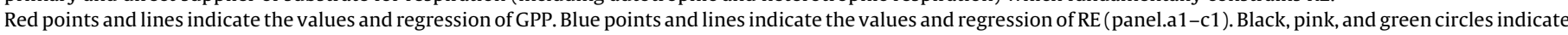

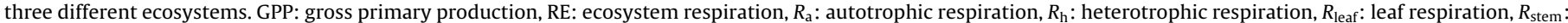

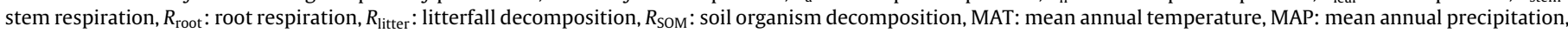
EVI: enhanced vegetation index, and Es: ecosystem.

space (Fig. 4(a-c)). The results were in good agreement with most regional studies. The spatial variations in GPP and RE both show linear responses to MAT and MAP in China (Yu et al., 2013), and exhibit increases with MAT and IWA (water index) across the European forest ecosystems (Reichstein et al., 2007b). Studies also indicate that the spatial variations in GPP and RE consistently linearly respond to MAT and MAP in evergreen broadleaf forests and grasslands (Yuan et al., 2009).

Given that GPP and RE respond in similar ways to the climatic and vegetation variables across space, the RE/GPP value was speculated not to increase along the variations in climatic and vegetation factors. Our results demonstrate that the RE/GPP values consistently averaged at 0.87 along the variations in climatic and vegetation factors based on the available sites in the study. RE/GPP values of more than $85 \%$ of the terrestrial ecosystems fluctuated within the range of $0.7-1.2$ (Fig. 5). This range of RE/GPP was in good agreement with the experimental results $(0.78-1.24)$, which shows that RE is nearly $1.25-2$ times soil respiration $R_{\mathrm{S}}$ (Janssens et al., 2001; Law et al., 1999), and $R_{\mathrm{S}}$ averages $24 \%$ higher than the mean annual NPP (Raich and Schlesinger, 1992) which accounts for 50\% of GPP (Delucia et al., 2007; Griffis et al., 2004; Waring et al., 1998).

Finally, the influence of the climatic and vegetation variables on the spatial variation in RE was found to primarily act by impacting the spatial variation in GPP, and GPP is the primary direct driver for the spatial variation in RE (Fig. 6). This is likely because photosynthesis supplies photosynthate for respiration. From the physiological viewpoint, respiration is, in essence, the process of mitochondrial oxidation of carbohydrates, which ultimately depends on the carbohydrates from photosynthesis (Atkin and Tjoelker, 2003). At the ecosystem level, each component of ecosys- tem respiration is linked to the photosynthate supply (Chapin et al., 2011).

RE consists of autotrophic respiration by plants $\left(R_{\mathrm{a}}\right)$ and heterotrophic respiration by soil animals and microbes $\left(R_{\mathrm{h}}\right)$. Autotropic respiration $\left(R_{\mathrm{a}}\right)$ functions to provide energy for plant growth and maintenance, in which growth respiration $\left(R_{\text {growth }}\right)$ is in relatively constant proportion to GPP throughout a wide range of ecosystems (Waring et al., 1998). The most variable part of $R_{\mathrm{a}}$, maintenance respiration $\left(R_{\text {maint }}\right)$, is expected to be higher in ecosystems with higher production (Chapin et al., 2011). Moreover, the magnitude of root respiration $\left(R_{\text {root }}\right)$ is also directly driven by new canopy photosynthate (Ekblad and Högberg, 2001; Högberg et al., 2001), which is usually transferred to the root system within 1-4 days in forests (Ekblad and Högberg, 2001). Approximately 15-25\% of the photosynthate would be excreted to the rhizosphere to stimulate the growth and activity of mycorrhizal fungi around the root system (Kuzyakov, 2002), thus influencing RE.

Heterotropic respiration $\left(R_{\mathrm{h}}\right)$ derives from the decomposition of soil organic matter, which seems to be independent from GPP. However, soil microbes tend to preferentially decompose young organic matter (Parton et al., 1987; Schimel et al., 1994), which comes directly from the photosynthate supply. Moreover, ecosystems with high photosynthetic capacity and productivity tend to have short leaf spans, large specific leaf areas, high leaf nitrogen contents, and thus, high litterfall quantity and quality (Chapin et al., 2002) that significantly influence the magnitude of $R_{\mathrm{h}}$ (BondLamberty et al., 2004; Raich and Nadelhoffer, 1989).

Based on the evidence above, we simply concluded that the covariation between GPP and RE across space is largely attributed to the parallel responses of GPP and RE to the common climatic and vegetation variables. However, the underlying eco-physiological 
mechanism lies in productivity as the primary and direct supplier of substrate for respiration, which fundamentally constrains RE. Disturbances may drive GPP and RE deviation at some sites, but do not dominate the large-scale covaried GPP and RE pattern across space as observed by the eddy covariance flux tower network, which potentially is biased toward sampling mature, undisturbed ecosystems (Fig. 7).

\subsection{The ecological implications of the covariation between GPP and $R E$ across space}

Ecosystem respiration shows great variability across space. In subarctic deciduous needle-leaved forests, $\mathrm{RE}$ is lower than $200 \mathrm{~g} \mathrm{C} \mathrm{m}^{-2} \mathrm{yr}^{-1}$, while $\mathrm{RE}$ can reach approximately $4000 \mathrm{~g} \mathrm{C} \mathrm{m}^{-2} \mathrm{yr}^{-1}$ in evergreen broad-leaved forests (Chen et al., 2013; Hirata et al., 2008). Temperature and precipitation are deemed the two critical climatic drivers for the variations in RE across space (Chen et al., 2013; Hirata et al., 2008; Yu et al., 2013). However, as revealed in this study, the impacts of environmental factors on the spatial variations in RE occurred mainly through their direct effects on the spatial variations in GPP. The spatial variation in GPP, which determines the differences in the photosynthate availability for respiration, is the dominant driver for the discrepancy in respiration across space. Hence, photosynthate availability (GPP) must be fully considered when comparing RE across different sites.

Based on the data currently available in this study, we evaluated the global RE/GPP was averaged at 0.87. Given that the global GPP was estimated to be $119-123 \mathrm{Pg} \mathrm{C} \mathrm{m}^{-2} \mathrm{yr}^{-1}$ in the IPCC AR4 and data-oriented machine model (Beer et al., 2010; Denman et al., 2007), we can evaluate that the global RE was approximately $104-107 \mathrm{Pg} \mathrm{C} \mathrm{m}^{-2} \mathrm{yr}^{-1}$. This result is in good agreement with model prediction of global RE as $96 \pm 6 \mathrm{PgC} \mathrm{m}^{-2} \mathrm{yr}^{-1}$ (Jung et al., 2011). It implies that knowledge of the RE/GPP value for a variety of regions and biome types would be an essential source of understanding for ecosystem science, as well as a valuable validation dataset for modeling and remote sensing to upscale the carbon budget estimations. While we should note that the upscaled NEP or GPP/RE does not fully account for disturbance or other sources of net biome productivity, including lateral transport and anthropogenic harvest, and thus, is not directly comparable to the strength of the global land sink.

RE/GPP value (1-NEP/GPP) is also a direct parameter that represents the ecosystem carbon use efficiency. In this study, RE/GPP was not significantly different among the six regions, but grasslands tended to have a higher RE/GPP than the other ecosystems. It is partly associated with the fast turnover rate and the water stress conditions in grasslands (Fu et al., 2006). Several significant deviations in global RE/GPP values were also observed. This finding implies that some potential factors may drive RE/GPP at some sites to deviate from the balance, such as (1) nitrogen deposition may break the balance between the nutrient needs for photosynthesis and respiration and result in altering RE/GPP (Magnani et al., 2007), (2) disturbance events (e.g., clear-cuts, harvests, and fires) would significantly affect RE/GPP by reducing GPP by decreasing leaf area, but enhancing RE through a sufficient substrate supply and favorable decomposition environment (Krishnan et al., 2009). As a result, research to further identify the differences in ecosystem responses to climate change and disturbances might be the key to answer the observed deviation in RE/GPP and the large variations in NEE.

\subsection{Uncertainties in the covariation between GPP and RE across space}

This study has several sources of uncertainties. First, we should note that certain degrees of self-correlation are likely introduced during the NEE partitioning process (Vickers et al., 2009). Because GPP is calculated from the difference between NEE and RE, a correlation analysis of GPP vs. RE may lead to self-correlation of the type $X+Y$ vs. $Y$ (Brett, 2004). We followed the equation after Brett (2004) to examine the potential bias caused by the self-correlation. The result indicated that the self-correlations were about 3-32\% in the GPP and RE relationships for the six regions, and approximately $21 \%$ at the global scale (Table 4). When the self-correlation was excluded, the spatial variations in GPP were estimated to explain $60-76 \%$ of the variations in RE in the six regions, and 70\% of RE variations at the global scale. We further used independent GPP data derived from the MODIS remote sensing product (MOD17A2_51) to test the robustness of the relationship between GPP and RE across space. The result showed that GPP derived from MODIS inversion and RE derived from eddy covariance measurements similarly and significantly covaried across space, and the spatial variations in GPP were estimated to explain $60 \%$ of the RE variations at the global scale (Fig. S4). These results indicated that the potential bias caused by the current flux partitioning on the covariation between GPP and RE fell within 20-30\% even involving some uncertainties derived from MODIS GPP inversion (Zhao and Running, 2006) and the self-correlation algorithm itself (Brett, 2004). This result provides a most possibly reasonable estimate only based on our current flux partitioning algorithm. At present it is still unable to obtain direct, independent observations of either GPP or RE, because these two processes happen simultaneously and consist of a multitude of responses by organisms. In the future combining the stable isotope technique and high-frequency eddy covariance measurement (Bowling et al., 2001; Scanlon and Kustas, 2010; Thomas et al., 2008; Zobitz et al., 2007, 2008) to partition the net ecosystem exchange into independent GPP and RE would be helpful to more accurately assess the relationships between GPP and RE. This promising isotope partitioning approach needs further overcome the constraints of measurement precision of the isotope fluxes, high sensitivity to $\mathrm{CO}_{2}$ conductance and short-term variability in $\mathrm{RE}$ in the future (Griffis, 2013).

Additionally, we should note that several uncertainties in our estimation may originate from random errors caused by the influences of complex topography, atmospheric stability, the frequency response of data acquisition, and advection or storage under stable nighttime conditions during the eddy covariance measurements (Loescher et al., 2006), and from data statistical analysis in the processes of outlier removal, gap-filling, flux partitioning, and integrated analysis, as well as from the limited and uneven sampling, because the established flux towers tend to bias toward the Northern Hemisphere, and toward the mature, established ecosystems. To further improve our understanding of variations in carbon flux, we propose additions of flux measurements in the Southern Hemisphere and in different successional stages ecosystems are needed.

Table 4

$R^{2}$ values for the observed correlation $\left(R^{2}{ }_{\text {obs }}\right)$, the self-correlation $\left(R^{2}{ }_{\mathrm{sc}}\right)$, and the subtractive correlation $\left(R^{2}\right)$ between GPP and RE.

\begin{tabular}{|c|c|c|c|c|c|}
\hline Regions & $\mathrm{CV}_{\mathrm{NEE}}$ & $\mathrm{CV}_{\mathrm{RE}}$ & $R_{\text {obs }}^{2}$ & $R_{\mathrm{sc}}^{2}$ & $R^{2}$ \\
\hline Asian & 1.17 & 0.82 & 0.92 & 0.32 & 0.60 \\
\hline European & 0.98 & 0.37 & 0.77 & 0.12 & 0.65 \\
\hline North American & 1.39 & 0.50 & 0.88 & 0.12 & 0.76 \\
\hline South American & 1.21 & 0.20 & 0.65 & 0.03 & 0.62 \\
\hline Oceanian & 1.03 & 0.57 & 0.98 & 0.23 & 0.75 \\
\hline African & 1.37 & 0.32 & 0.78 & 0.05 & 0.73 \\
\hline N.H. & 1.41 & 0.47 & 0.89 & 0.10 & 0.79 \\
\hline S.H. & 1.13 & 0.57 & 0.89 & 0.20 & 0.69 \\
\hline Global & 1.16 & 0.61 & 0.90 & 0.21 & 0.69 \\
\hline
\end{tabular}




\section{Conclusions}

By integrating global carbon flux (GPP and RE) data, we explored the correlation between the spatial variations in GPP and RE. The results indicated that:

(1) GPP and RE covaried across space in the six regions and at the global scale.

(2) RE/GPP values were not significantly different among the six regions or between the two hemispheres. RE/GPP values averaged at $0.87 \pm 0.04$ along the spatial variations in climate and vegetation index.

(3) The variation in photosynthate availability is the dominant driver for respiration across space and this process must be fully considered in the cross-site RE comparisons.

(4) In the future combining the stable isotope technique and high-frequency eddy covariance measurement to obtain independent estimates of GPP and RE is needed to more accurately assess the relationships between GPP and RE.

\section{Acknowledgements}

This research was supported by the the Key Program of National Natural Science Foundation of China (grant no. 31290221), the Chinese Academy of Sciences Strategic Priority Research Program (grant no. XDA05050602), the International Cooperation and Exchange Program of National Natural Science Foundation of China (grant no. 31420103917), and the National Key Research and Development Program (grant no. 2010CB833504). We acknowledge all researchers who contributed to the eddy covariance flux measurements for providing valuable data for this study. We also thank numerous reviewers for presenting valuable suggestions on this paper.

\section{Appendix A. Supplementary data}

Supplementary data associated with this article can be found, in the online version, at http://dx.doi.org/10.1016/j.agrformet. 2015.01.012.

\section{References}

Amiro, B.D., Barr, A.G., Barr, J.G., Black, T.A., Bracho, R., Brown, M., Chen, J., Clark K.L., Davis, K.J., Desai, A.R., Dore, S., Engel, V., Fuentes, J.D., Goldstein, A.H., Goulden, M.L., Kolb, T.E., Lavigne, M.B., Law, B.E., Margolis, H.A., Martin, T. McCaughey, J.H., Misson, L., Montes-Helu, M., Noormets, A., Randerson, J.T. Starr, G., Xiao, J., 2010. Ecosystem carbon dioxide fluxes after disturbance in forests of North America. J. Geophys. Res. 115, G00K02.

Atkin, O.K., Tjoelker, M.G., 2003. Thermal acclimation and the dynamic response of plant respiration to temperature. Trends Plant Sci. 8, 343-351.

Baldocchi, D., Falge, E., Gu, L., Olson, R., Hollinger, D., Running, S., Anthoni, P., Bernhofer, C., Davis, K., Evans, R., Fuentes, J., Goldstein, A., Katul, G., Law, B. Lee, X.H., Malhi, Y., Meyers, T., Munger, W., Oechel, W., Paw, U., Pilegaard, K.T., Schmid, K., Valentini, H.P., Verma, R., Vesala, S., Wilson, T., Wofsy, K., 2001. FLUXNET: a new tool to study the temporal and spatial variability of ecosystem-scale carbon dioxide, water vapor, and energy flux densities. Bull. Am. Meteorol. Soc. 82, 2415-2434.

Baldocchi, D., 2008. 'Breathing' of the terrestrial biosphere: lessons learned from a global network of carbon dioxide flux measurement systems. Aust. J. Bot. 56, $1-26$.

Beer, C., Reichstein, M., Tomelleri, E., Ciais, P., Jung, M., Carvalhais, N., Rödenbeck, C., Arain, M.A., Baldocchi, D., Bonan, G.B., Bondeau, A., Cescatti, A., Lasslop, G., Lindroth, A., Lomas, M., Luyssaert, S., Margolis, H., Oleson, K.W., Roupsard, O., Veenendaal, E., Viovy, N., Williams, C., Woodward, F.I., Papale, D., 2010. Terrestrial gross carbon dioxide uptake: global distribution and covariation with climate. Science $329,834-838$.

Bond-Lamberty, B., Wang, C.K., Gower, S.T., 2004. A global relationship between the heterotrophic and autotrophic components of soil respiration? Global Change Biol. 10, 1756-1766.

Bowling, D.R., Tans, P.P., Monson, R.K., 2001. Partitioning net ecosystem carbon exchange with isotopic fluxes of $\mathrm{CO}_{2}$. Glob Chang Biol. 7, 127-145.

Brett, M.T., 2004. When is a correlation between non-independent variables spurious? Oikos 105, 647-656.
Ciais, P., Reichstein, M., Viovy, N., Granier, A., Ogée, J., Allard, V., Aubinet, M. Buchmann, N., Bernhofer, C., Carrara, A., Chevallier, F., De Noblet, N., Friend, A.D., Friedlingstein, P., Grunwald, T., Heinesch, B., Keronen, P., Knohl, A., Krinner, G., Loustau, D., Manca, G., Matteucci, G., Miglietta, F., Ourcival, J.M., Papale, D., Pilegaard, K., Rambal, S., Seufert, G., Soussana, J.F., Sanz, M.J., Schulze, E.D., Vesala, T., Valentini, R., 2005. Europe-wide reduction in primary productivity caused by the heat and drought in 2003. Nature 437, 529-533.

Chapin III, F.S., Matson, P.A., Matson, P.A., Mooney, H.A., 2002. Principles of terrestrial ecosystem ecology. Springer-Verlag, New York, pp. 123-228.

Chapin III, F.S., Matson, P.A., Vitousek, P.M., 2011. Principles of terrestrial ecosystem ecology. Springer, New York, pp. 97-175.

Chen, Z., Yu, G.R., Ge, J.P., Sun, X.M., Hirano, T., Saigusa, N., Wang, Q.F., Zhu, X.J., Zhang, Y.P., Zhang, J.H., Yan, J.H., Wang, H.M., Zhao, L., Wang, Y.F., Shi, P.L., Zhao, F.H., 2013. Temperature and precipitation control of the spatial variation of terrestrial ecosystem carbon exchange in the Asian region. Agric. For. Meteorol. 182-183, 266-276.

Delucia, E., Drake, J.E., Thomas, R.B., Gonzalez-Meler, M., 2007. Forest carbon use efficiency: is respiration a constant fraction of gross primary production? Global Change Biol. 13, 1157-1167.

Denman, K.L., et al., 2007. Couplings between changes in the climate system and biogeochemistry, in climate change 2007: the physical science basis. In: Solomon, S., et al. (Eds.), Contribution of Working Group I to the Fourth Assessment Report of the Intergovernmental Panel on Climate Change. Cambridge University Press, Cambridge, U.K, pp. 499-587.

Desai, A.R., Richardson, A.D., Moffat, A.M., Kattge, J., Hollinger, D.Y., Barr, A., Falge, E., Noormets, A., Papale, D., Reichstein, M., Stauch, V.J., 2008. Cross-site evaluation of eddy covariance GPP and RE decomposition techniques. Agric. For. Meteorol. 148, 821-838.

Dore, S., Kolb, T.E., Montes-Helu, M., Eckert, S.E., Sullivan, B.W., Hungate, B.A., Kaye J.P., Hart, S.C., Koch, G.W., Finkral, A., 2010. Carbon and water fluxes from ponderosa pine forests disturbed by wildfire and thinning. Ecol. Appl. 20, 663-683.

Dunn, A.L., Barford, C.C., Wofsy, S.C., Goulden, M.L., Daube, B.C., 2007. A long-term record of carbon exchange in a boreal black spruce forest: means responses to interannual variability, and decadal trends. Global Change Biol. 13, 577-590.

Ekblad, A., Högberg, P., 2001. Natural abundance of ${ }^{13} \mathrm{C}$ in $\mathrm{CO}_{2}$ respired from forest soils reveals speed of link between tree photosynthesis and root respiration. Oecologia 127, 305-308.

Falge, E., Baldocchi, D., Olson, R., Anthoni, P., Aubinet, M., Bernhofer, C., Burba, G. Ceulemans, R., Clement, R., Dolman, H., Granier, A., Gross, P., Grünwald, T., Hollinger, D., Jensen, N.O., Katulm, G., Keronen, P., Kowalski, A., Lai, C.T., Law, B.E., Meyers, T., Moncrieff, J., Moorsi, E., Mungerp, W.J., Pilegaard, K., Rannik, Ü., Rebmannq, C., Suyker, A., Tenhunen, J., Tu, K., Verma, S., Vesala, T., Wilson, K., Wofsy, S., 2001. Gap filling strategies for defensible annual sums of net ecosystem exchange. Agric. For. Meteorol. 107, 43-69.

Falge, E., Baldocchi, D., Tenhunen, J., Aubinet, M., Bakwin, P., Berbigier, P., Bernhofer, C., Burba, G., Clement, R., Davis, K.J., Elbers, J.A., Goldstein, A.H., Grelle, A., Granier, A., Gundmundsson, J., Hollinger, D., Kowalski, A.S., Katul, G., Law, B.E., Malhi, Y., Meyers, T., Monson, R.K., Munger, J.W., Oechel, W., Paw, U., Pilegaard, K.T., Rannik, K., Rebmann, U., Suyker, C., Valentini, A.E., Wilson, R., Wofsy, K., 2002. Seasonality of ecosystem respiration and gross primary production as derived from FLUXNET measurements. Agric. For. Meteorol. 113, 53-74.

Fu, Y.L., Yu, G.R., Wang, Y.F., Li, Z.Q., Hao, Y.B., 2006. Effect of water stress on ecosystem photosynthesis and respiration of a Leymus chinensis steppe in inner mongolia. Sci. China Ser. D Earth Sci. 49, 196-206.

Gilmanov, T.G., Verma, S.B., Sims, P.L., Meyers, T.P., Bradford, J.A., Burba, G.G. Suyker, A.E., 2003. Gross primary production and light response parameters of four southern plains ecosystems estimated using long-term $\mathrm{CO}_{2}$-flux tower measurements. Global Biogeochem. Cycle 17, 1071.

Göckede, M., Rebmann, C., Foken, T., 2004. A combination of quality assessment tools for eddy covariance measurements with footprint modelling for the characterisation of complex sites. Agric. For. Meteorol. 127, 175-188.

Goulden, M.L., Miller, S.D., Da Rocha, H.R., Menton, M.C., De Freitas, H.C., Silva Figueira, E., De Sousa, A.M., 2004. Diel and seasonal patterns of tropical forest $\mathrm{CO}_{2}$ exchange. Ecol. Appl. 14, S42-S54.

Granier, A., Reichstein, M., Bréda, N., Janssens, I.A., Falge, E., Ciais, P., Grünwald, T. Aubinet, M., Berbigier, P., Bernhofer, C., Buchmann, N., Facini, O., Grassi, G., Heinesch, B., Ilvesniemi, H., Keronen, P., Knohl, A., Köstner, B., Lagergren, F., Lindroth, A., Longdoz, B., Loustau, D., Mateus, J., Montagnani, L., Nys, C., Moors, E., Papale, D., Peiffer, M., Pilegaard, K., Pita, G., Pumpanen, J., Rambal, S. Rebmann, C., Rodrigues, A., Seufert, G., Tenhunen, J., Vesala, T., Wang, Q., 2007. Evidence for soil water control on carbon and water dynamics in European forests during the extremely dry year: 2003. Agric. For. Meteorol. 143, 123-145

Griffis, T.J., Black, T.A., Gaumont-Guay, D., Drewitt, G.B., Nesic, Z., Barr, A.G. Morgenstern, K., Kljun, N., 2004. Seasonal variation and partitioning of ecosystem respiration in a Southern boreal Aspen forest. Agric. For. Meteorol. $125,207-223$.

Griffis, T.J., 2013. Tracing the flow of carbon dioxide and water vapor between the biosphere and atmosphere: a review of optical isotope techniques and their application. Agric. For. Meteorol. 174-175, 85-109.

Haslwanter, A., Hanmmerle, A., Wohlfahrt, G., 2009. Open-path vs. closed-path eddy covariance measurements of the net ecosystem carbon dioxide and water vapour exchange: a long-term perspective. Agric. For. Meteorol. 149, 291-302. 
Hirata, R., Saigusa, N., Yamamoto, S., Ohtani, Y., Ide, R., Asanuma, J., Gamo, M., Hirano, T., Kondo, H., Kosugi, Y., Li, S.G., Nakai, Y., Takagi, K., Tani, M., Wang, H.M., 2008. Spatial distribution of carbon balance in forest ecosystems across East Asia. Agric. For. Meteorol. 148, 761-775.

Högberg, P., Nordgren, A., Buchmann, N., Taylor, A.F.S., Ekblad, A., Högberg, M.N., Nyberg, G., Ottosson-Löfvenius, M., Read, D.J., 2001. Large-scale forest girdling shows that current photosynthesis drives soil respiration. Nature 411 , 789-792.

Huete, A., Didan, K., Miura, T., Rodriguez, E.P., Gao, X., Ferreira, L.G., 2002. Overview of the radiometric and biophysical performance of the MODIS vegetation indices. Remote Sens. Environ. 83, 195-213.

Hussain, M.Z., Grunwald, T., Tenhunen, J.D., Li, Y.L., Mirzae, H., Bernhofer, C., Otieno, D., Dinh, N.Q., Schmidt, M., Wartinger, M., Owen, K., 2011. Summer drought influence on $\mathrm{CO}_{2}$ and water fluxes of extensively managed grassland in Germany. Agric. Ecosyst. Environ. 141, 67-76.

Huxman, T.E., Turnipseed, A.A., Sparks, J.P., Harley, P.C., Monson, R.K., 2003. Temperature as a control over ecosystem $\mathrm{CO}_{2}$ fluxes in a high-elevation, subalpine forest. Oecologia 134, 537-546.

Janssens, I.A., Lankreijer, H., Matteucci, G., Kowalski, A.S., Buchmann, N., Epron, D., Pilegaard, K., Kutsch, W., Longdoz, B., Grünwald, T., Montagnani, L., Dore, S., Rebmann, C., Moors, E.J., Grelle, A., Rannik, U., Morgenstern, K., Oltchev, S. Clement, R., Gudmundsson, J., Minerbi, S., Berbigier, P., Ibrom, A., Moncrieff, J. Aubinet, M., Bernhofer, C., Jsensen, N.O., Vesala, T., Granier, A., Schulze, E.D., Lindroth, A., Dolman, A.J., Jarvis, P.G., Ceulemans, R., Valentini, R., 2001. Productivity overshadows temperature in determining soil and ecosystem respiration across European forests. Global Change Biol. 7, 269-278.

Jung, M., Reichstein, M., Margolis, H.A., Cescatti, A., Richardson, A.D., Arain, M.A. Arneth, A.M., Bernhofer, C., Bonal, D., Chen, J.Q., Gianelle, D., Gobron, N., Kiely, G., Kutsch, W., Lasslop, G., Law, B.E., Lindroth, A., Merbold, L., Montagnani, L., Moors, E.J., Papale, D., Sottocornola, M., Vaccari, F., Williams, C., 2011. Global patterns of land-atmosphere fluxes of carbon dioxide, latent heat, and sensible heat derived from eddy covariance, satellite, and meteorological observations. J. Geophys. Res. 116, G00J07.

Krishnan, P., Black, T.A., Jassal, R.S., Chen, B.Z., Nesic, Z., 2009. Interannual variability of the carbon balance of three different-aged Douglas-fir stands in the Pacific Northwest. J. Geophys. Res. 114, G04011.

Kuzyakov, Y., 2002. Review: factors affecting rhizosphere priming effects. J. Plant Nutr. Soil Sci. 165, 382-396.

Lal, R, 2012. Climate change mitigation by managing the terrestrial biosphere. Recarbonization of the Biosphere. Springer, pp. 17-39.

Lasslop, G., Reichstein, M., Papale, D., Richardson, A.D., Arneth, A., Barr, A., Stoy, P., Wohlfahrt, G., 2010. Separation of net ecosystem exchange into assimilation and respiration using a light response curve approach: critical issues and global evaluation. Global Change Biol. 16, 187-208.

Law, B.E., Ryan, M.G., Anthoni, P.M., 1999. Seasonal and annual respiration of a ponderosa pine ecosystem. Global Change Biol. 5, 169-182.

Law, B.E., Falge, E., Gu, L., Baldocchi, D.D., Bakwin, P., Berbigier, P., Davis, K., Dolman, A.J., Falk, M., Fuentes, J., Goldstein, A., Granier, A., Grelle, A., Hollinger D., Janssens, I.A., Jarvis, P., Jensen, N.O., Katul, G., Mahli, Y., Matteucci, G., Meyers, T., Monson, R., Munger, W., Oechel, W., Olson, R., Pilegaard, K., Paw, U., Thorgeirsson, K.T., Valentini, H., Verma, R., Vesala, S., Wilson, T., Wofsy, K., 2002. Environmental controls over carbon dioxide and water vapor exchange of terrestrial vegetation. Agric. For. Meteorol. 113, 97-120.

Li, C.C., 1981. Path analysis: a primer, 3rd ed. Boxwood, Pacific Grove, Calif.

Lloyd, J., Taylor, J.A., 1994. On the temperature dependence of soil respiration. Funct. Ecol., 315-323.

Loescher, H.W., Law, B.E., Mahrt, L., Hollinger, D.Y., Campbell, J., Wofsy, S.C., 2006 Uncertainties in, and interpretation of, carbon flux estimates using the eddy covariance technique. J. Geophys. Res. 111, D21S90.

Luyssaert, S., Inglima, I., Jung, M., Richardson, A.D., Reichstein, M., Papale, D., Piao, S.L., Schulze, E.D., Wingate, L., Matteucci, G., Aragao, L., Aubinet, M., Beer, C. Bernhofer, C., Black, K.G., Bonal, D., Bonnefond, J.M., Chambers, J., Ciais, P., Cook, B., Davis, K.J., Dolman, A.J., Gielen, B., Goulden, M., Grace, J., Granier, A., Grelle, A., Griffis, T., Grünwald, T., Guidolotti, G., Hanson, P.J., Harding, R. Hollinger, D.Y., Hutyra, L.R., Kolari, P., Kruijt, B., Kutsch, W., Lagergren, F., Laurila, T., Law, B.E., Lemaire, G., Lindroth, A., Loustau, D., Malhi, Y., Mateus, J., Migliavacca, M., Misson, L., Montagnani, L., Moncrieff, J., Moors, E., Munger, J.W., Nikinmaa, E., Ollinger, S.V., Pita, G., Rebmann, C., Roupsard, O., Saigusa, N., Sanz, M.J., Seufert, G., Sierra, C., Smith, M.L., Tang, J., Valentini, R., Vesala, T., Janssens, I.A., 2007. $\mathrm{CO}_{2}$ balance of boreal temperate, and tropical forests derived from a global database. Global Change Biol. 13, 2509-2537.

Magnani, F., Mencuccini, M., Borghetti, M., Berbigier, P., Berninger, F., Delzon, S., Grelle, A., Hari, P., Jarvis, P.G., Kolari, P., Kowalski, A.S., Lankreijer, H., Law, B.E. Lindroth, A., Loustau, D., Manca, G., Moncrieff, J.B., Rayment, M., Tedeschi, V., Valentini, R., Grace, J., 2007. The human footprint in the carbon cycle of temperate and boreal forests. Nature 447, 848-850.

Migliavacca, M., Reichstein, M., Richardson, A.D., Colombo, R., Sutton, M.A., Lasslop, G., Tomelleri, E., Wohlfahrt, G., Carvalhais, N., Cescatti, A., Mahecha, M.D., Montagnani, L., Papale, D., Zaehle, S., Arain, A., Arneth, A., Black, T.A., Carrara A., Dore, S., Gianelle, D., Helfter, C., Hollinger, D., Kutsch, W.L., Lafleur, P.M., Nouvellon, Y., Rebmann, C., Da Rocha, H.R., Rodeghiero, M., Roupsard, O., Sebastià, M.T., Seufert, G., Soussan, J.F., Van Der Molen, M.K., 2011. Semiempirical modeling of abiotic and biotic factors controlling ecosystem respiration across eddy covariance sites. Global Change Biol. 17, 390-409.

Moffat, A.M., Papale, D., Reichstein, M., Hollinger, D.Y., Richardson, A.D., Barr, A.G., Beckstein, C., Braswell, B.H., Churkina, G., Desai, A.R., Falge, E., Gove, J.H.,
Heimann, M., Hui, D.F., Jarvis, A.J., Kattge, J., Noormets, A., Stauch, V.J., 2007. Comprehensive comparison of gap-filling techniques for eddy covariance net carbon fluxes. Agric. For. Meteorol. 147 (2), 9-232.

Papale, D., Reichstein, M., Canfora, E., Aubinet, M., Bernhofer, C., Longdoz, B. Kutsch, W., Rambal, S., Valentini, R., Vesala, T., Yakir, D., 2006. Towards a more harmonized processing of eddy covariance $\mathrm{CO}_{2}$ fluxes: algorithms and uncertainty estimation. Biogeosciences 3 (4), 571-583.

Parton, W.J., Schimel, D.S., Cole, C.V., Ojima, D.S., 1987. Division s-3-soil microbiology and biochemistry. Soil Sci. Soc. Am. J. 51, 1173-1179.

Raich, J.W., Nadelhoffer, K.J., 1989. Belowground carbon allocation in forest ecosystems: global trends. Ecology 70, 1346-1354.

Raich, J.W., Schlesinger, W.H., 1992. The global carbon dioxide flux in soil respiration and its relationship to vegetation and climate. Tellus Ser. B 44, 81-99.

Reichstein, M., Falge, E., Baldocchi, D., Papale, D., Aubinet, M., Berbigier, P., Bernhofer, C., Buchmann, N., Gilmanov, T., Granier, A., Grünwald, T. Havrankova, K., Ilvesniemi, H., Janous, D., Knohl, A., Laurila, T., Lohila, A. Loustau, D., Matteucci, G., Meyers, T., Miglietta, F., Ourcival, J.M., Pumpanen, J., Rambal, S., Rotenberg, E., Sanz, M., Tenhunen, J., Seufert, G., Vaccari, F., Vesala, T., Yakir, D., Valentini, R., 2005. On the separation of net ecosystem exchange into assimilation and ecosystem respiration: review and improved algorithm. Global Change Biol. 11, 1424-1439.

Reichstein, M., Ciais, P., Papale, D., Valentini, R., Running, S., Viovy, N., Cramer, W., Granier, A., Ogée, J., Allard, V., Aubinet, M., Bernhofer, C., Buchmann, N., Carrara, A., Grünwald, T., Heimann, M., Heinesch, B., Knohl, A., Kutsch, W., Loustau, D. Manca, G., Matteucci, G., Miglietta, F., Ourcival, J.M., Pilegaard, K., Pumpanen, J., Rambal, S., Schaphoff, S., Seufer, G., Soussana, J.F., Sanz, M.J., Vesala, T., Zhao, M., 2007a. Reduction of ecosystem productivity and respiration during the European summer 2003 climate anomaly: a joint flux tower, remote sensing and modelling analysis. Global Change Biol. 13, 634-651.

Reichstein, M., Papale, D., Valentini, R., Aubinet, M., Bernhofer, C., Knohl, A., Laurila T., Lindroth, A., Moors, E., Pilegaard, K., Seufert, G., 2007b. Determinants of terrestrial ecosystem carbon balance inferred from European eddy covariance flux sites. Geophys. Res. Lett. 34, L01402.

Rodrigues, A., Pita, G., Mateus, J., Kurz-Besson, C., Casquilho, M., Cerasoli, S., Gomes, A., Pereira, J., 2011. Eight years of continuous carbon fluxes measurements in a Portuguese eucalypt stand under two main events: drought and felling. Agric For. Meteorol. 151, 493-507.

Scanlon, T.M., Kustas, W.P., 2010. Partitioning carbon dioxide and water vapor fluxes using correlation analysis. Agric. For. Meteorol. 150, 89-99.

Schimel, D.S., Braswell, B.H., Holland, E.A., McKeown, R., Ojima, D.S., Painter, T.H. Parton, W.J., Townsend, A.R., 1994. Climatic, edaphic, and biotic controls over storage and turnover of carbon in soils. Global Biogeochem. Cycles 8 279-293.

SPSS, 2007. SPSS Inc. Released. SPSS for Windows, Version 16.0, Chicago.

Stoy, P.C., Katul, G.G., Siqueira, M.B.S., Juang, J.Y., Novick, K.A., Uebelherr, J.M., Oren, R., 2006. An evaluation of models for partitioning eddy covariance-measured net ecosystem exchange into photosynthesis and respiration. Agric. For. Meteorol. 141, 2-18.

Thomas, C., Martin, J.G., Goeckede, M., Siqueira, M.B., Foken, T., Law, B.E., Loescher, H.W., Katul, G., 2008. Estimating daytime subcanopy respiration from conditional sampling methods applied to multi-scalar high frequency turbulence time series. Agric. For. Meteorol. 148, 1210-1229.

Thomas, C.K., Law, B.E., Irvine, J., Martin, J.G., Pettijohn, J.C., Davis, K.J., 2009 Seasonal hydrology explains interannual and seasonal variation in carbon and water exchange in a semiarid mature ponderosa pine forest in central Oregon. J. Geophys. Res. 114, G04006.

Vickers, D., Thomas, C.K., Martin, J.G., Law, B., 2009. Self-correlation between assimilation and respiration resulting from flux partitioning of eddy-covariance $\mathrm{CO}_{2}$ fluxes. Agric. For. Meteorol. 149, 1552-1555.

Waring, R.H., Landsberg, J.J., Williams, M., 1998. Net primary production of forests: a constant fraction of gross primary production? Tree Physiol. 18 129-134.

Wilkinson, M., Eaton, E.L., Broadmeadow, M.S.J., Morison, J.I.L., 2012. Inter-annual variation of carbon uptake by a plantation oak woodland in South-Eastern England. Biogeosciences 9, 5373-5389.

Yu, G.R., Zhang, L.M., Sun, X.M., Fu, Y.L., Wen, X.F., Wang, Q.F. Li, S.G., Ren, C.Y. Song, X., Liu, Y.F., Han, S.J., Yan, J.H., 2008. Environmental controls over carbon exchange of three forest ecosystems in eastern China. Global Change Biol. 14 2555-2571.

Yu, G.R., Zhu, X.J., Fu, Y.L., He, H.L., Wang, Q.F., Wen, X.F., Li, X.R., Zhang, L.M., Zhang, L., Su, W., Li, S.G., Sun, X.M., Zhang, Y.P., Zhang, J.H., Yan, J.H., Wang, H.M., Zhou, G.S., Jia, B.R., Xiang, W.H., Li, Y.N., Zhao, L., Wang, Y.F., Shi, P.L., Chen, S.P., Xin, X.P., Zhao, F.H., Wang, Y.Y., Tong, C.L., 2013. Spatial patterns and climate drivers of carbon fluxes in terrestrial ecosystems of China. Global Change Biol. 19, 798-810.

Yuan, W., Luo, Y., Richardson, A.D., Oren, R.A.M., Luyssaert, S., Janssens, I.A., Ceulemans, R., Zhou, X., Grünwald, T., Aubinet, M., Berhofer, C., Baldocchi, D.D. Chen, J., Dunn, A.L., Deforest, J.L., Dragoni, D., Goldstein, A.H., Moors, E., William Munger, J., Monson, R.K., Suyker, A.E., Starr, G., Scott, R.L., Tenhunen, J., Verma, S.B., Vesala, T., Wofsy, S.C., 2009. Latitudinal patterns of magnitude and interannual variability in net ecosystem exchange regulated by biological and environmental variables. Global Change Biol. 15, 2905-2920.

Zhao, M.S., Running, S.W., 2006. Sensitivity of moderate resolution imaging spectroradiometer (MODIS) terrestrial primary production to the accuracy of meteorological reanalyses. J. Geophys. Res. 111, G01002. 
Zobitz, J.M., Burns, S.P., Ogee, J., Reichstein, M., Bowling, D.R., 2007. Partitioning net ecosystem exchange of $\mathrm{CO}_{2}$ in a high-elevation subalpine forest: comparison of a Bayesian/isotope approach to environmental regression methods. J. Geophys. Res. 112, G03013.
Zobitz, J.M., Burns, S.P., Reichstein, M., Bowling, D.R., 2008. Partitioning net ecosystem carbon exchange and the carbon isotopic disequilibrium in a subalpine forest. Global Chang Biol. 14, 1-16. 